\title{
PERAN ORANG TUA DALAM MENINGKATKAN MINAT BELAJAR ANAK PADA MASA PANDEMI COVID-19
}

\author{
Sintia Septiani ${ }^{1}$, Dr. Oyoh Bariah ${ }^{2}$, Khalid Ramdhani ${ }^{3}$ \\ ${ }^{1}$ Universitas Singaperbangsa Karawang. \\ ${ }^{3}$ Universitas Singaperbangsa Karawang. \\ ${ }^{2}$ Universitas Singaperbangsa Karawang.

\begin{abstract}
E-mail: ${ }^{1}$ 1710631110135@,student.unsika.ac.id, ${ }^{2}$ oyoh.bariah@staff.unsika.ac.id, ${ }^{3}$ Khalid.ramdhani@fai.unsika.ac.id
\end{abstract}

\begin{abstract}
Abstrak
Orang tua mempunyai peranan yang sangat penting dalam kehidupan dan tumbuh kembang anak, apalagi lingkungan keluarga adalah pilar utama untuk membentuk baik buruknya pribadi manusia agar dapat berkembang dengan baik dalam bersikap dan berakhlak. Orang tua dapat berperan sebagai sumber pembimbing, pendidik seorang anak karena hal utama dimulai dari keluarga dan orang tua karena dari orang tua lah seorang anak pertama-tama menerima Pendidikan. Pada saat ini sistem pembelajaran mengalami perubahan dikarenakan dengan adanya pandemi covid-19 menjadikan semua kegiatan belajar dilakukan sepenuhnya di rumah. Tetapi dalam perannya sebagai seorang pengajar dan pembimbing untuk anaknya orang tua juga masih mempunyai keterbatasan-keterbatasan yang menghambat perannya untuk membantu anak dalam belajar. Tujuan penelitian ini adalah untuk mengetahui peran orang tua dalam meningkatkan minat belajar anak pada masa pandemi covid-19. Penelitian yang peneliti lakukan adalah penelitian kualitatif deskriptif dengan metode pengumpulan data melalui wawancara. Sampel penelitian ini adalah orang tua di Desa Plawad, Karawang Timur. Hasil dari penelitian ini adalah orang tua dapat meningkatkan minat belajar anak pada masa pandemi covid-19 yaitu orang tua dapat menambah kedekatan hubungan dengan anaknya dan orang tua dapat melihat langsung perkembangan kemampuan anaknya dalam belajar. Peran orang tua selama pembelajaran online atau di rumah diantaranya sebagai pembimbing, fasilitator, dan motivator.
\end{abstract}

Kata Kunci: peran orang tua, minat belajar, pandemi covid-19

\footnotetext{
Abstract

Parents have a very important role in the life and development of children, especially the family environment is the main pillar to shape the good and bad of the human person so that they can develop well in attitude and character. Parents can act as a source of guidance, educators of a child because the main thing starts from the family and parents because it is from parents that a child first receives education. At this time the learning system is undergoing changes due to the Covid-19 pandemic making all learning activities carried out entirely at home. However, in their role as teachers and mentors for their children, parents still have limitations that hinder their role in helping
} 
Jurnal Edumaspul, 5 (2), Year 2021 - 50

(Sintia Septiani,Oyoh Bariah, Khalid Ramdhani)

children learn. The purpose of this study was to determine the role of parents in increasing children's interest in learning during the covid-19 pandemic. The research that the researcher did was descriptive qualitative research with the method of collecting data through interviews. The sample of this study were parents in Plawad Village, East Karawang. The results of this study are parents can increase their children's interest in learning during the covid-19 pandemic, namely parents can increase their close relationship with their children and parents can see firsthand the development of their children's learning abilities. The role of parents during online or at home learning includes mentors, facilitators, and motivators.

Keywords: the role of parents, interest in learning, the covid-19 pandemic

\section{Pendahuluan}

Belakangan ini, hampir seluruh media pemberitaan diisi dengan topik seputar Pandemi Corona Virus Disease 2019 (COVID-19) atau biasa disebut dengan Virus Corona. Virus ini berawal dari kota Wuhan Tiongkok, menyebar dengan sangat cepat ke berbagai negara, salah satunya Indonesia. Sejak kasus pertama virus corona ini ditemukan pada bulan November 2019 lalu, jumlah kasus terus mengalami kenaikan yang sangat meningkat. Penyebaran virus Covid-19 yang sangat cepat menyebar mengakibatkan perubahan berbagai lingkungan kehidupan seperti ekonomi, sosial, dan juga kegiatan pendidikan terganggu di seluruh dunia dan sangat berdampak pada hak-hak Pendidikan para peserta didik di masa depan. Melihat penyebaran Covid-19 semakin meluas mengakibatkan pemerintah membuat aturan Sosial/physical Distancing dan Stay at home. Kebijakan menjaga jarak atau membatasi interaksi antara satu sama lain dan tetap tinggal di rumah ditetapkan pemerintah sebagai usaha untuk memutus mata rantai penyebaran virus Covid-19.

$$
\text { Menteri Pendidikan dan }
$$

Kebudayaan Nadiem Makarim pada Selasa, 24 Maret 2020, mengeluarkan Surat Edaran Nomor 4 Tahun 2020 tentang Pelaksanaan Kebijakan Pendidikan dalam masa darurat penyebaran virus Covid-19. Dalam surat edaran ini disebutkan bahwa tujuan dari pelaksanaan Belajar dari Rumah (BDR) adalah untuk memastikan seluruh hak peserta didik mendapatkan layanan Pendidikan selama darurat Covid-19, melindungi warga satuan Pendidikan dari dampak buruk Covid-19, mencegah penyebaran dan penularan virus Covid-19 di satuan pendidikan dan memastikan seluruh dukungan aspek psikologis (pikiran, perasaan dan perilaku) bagi pendidik, peserta didik dan orangtua. Pemberhentian tatap muka atau belajar mengajar secara langsung bukan berarti kegiatan belajar mengajar tidak dilakukan. Tidak bisa ditolak virus Covid-19 ini telah membuat dunia Pendidikan di Indonesia terganggu. (Kemendikbud, 2020)

Semua tingkatan pendidikan, mulai dari pendidikan anak usia dini, sekolah dasar (SD), sekolah menengah pertama (SMP), sekolah menengah atas/kejuruan (SMA/SMK), termasuk perguruan tinggi mengambil kebijakan untuk belajar di rumah dengan secara online/daring. Dengan mewabahnya virus Covid-19 yang menyebabkan berlakunya kebijakan Work From Home (WFH). Sehingga sekolah dan kampus secara nasional melaksanakan pembelajaran dengan sistem online/daring. Dengan keadaan seperti inilah yang menjadikan Pandemi Covid-19 berdampak serius terhadap sektor pendidikan secara global (Khasanah, Lestari, Rahman, \& Daniel, 2020).

Walaupun terdapat berbagai kelebihan, namun virus Covid-19 ini membuat semua guru harus melaksanakan aktivitas belajar mengajar melalui pembelajaran dalam jaringan (Daring). Pembelajaran daring atau online membutuhkan kreativitas dan inovasi dari peserta didik, sehingga ilmu yang akan diberikan tetap berjalan dengan lancar. Semua tenaga pendidik harus menguasai 
komunikasi dalam jaringan teknologi, yaitu dengan cara berkomunikasi dengan cara dimana penyampaian dan menerima pesan yang dilakukan melalui jaringan internet. Dengan munculnya virus Covid-19 kegiatan belajar mengajar yang awalnya dilaksankan di sekolah menjadi belajar di rumah melalui online/daring. Menurut Dewi (dalam (Khalimah, 2020) Pembelajaran daring dilaksanakan dengan menyesuaikan kemampuan masing-masing sekolah. Belajar daring (online) dapat menggunakan teknologi digital seperti google classroom, belajar di rumah, zoom, WhatsApp dan lainnya. Tapi yang harus tetap dilakukan yaitu pemberian tugas melalui pemantauan dan pendampingan guru dan orang tua melalui grup WhatsApp sehingga peserta didik benar-benar dapat belajar dengan fokus dengan adanya keadaan seperti ini dapat dipastikan adanya interaksi yang terjalin antara guru dengan orang tua.

Orang tua memiliki peran sentral dalam proses pendidikan dan pembelajaran sehingga orang tua memiliki tanggung jawab untuk dapat memberikan semangat atau meningkatkan minat belajar kepada anaknya. Maka dari itu penelitian ini bertujuan untuk mengetahui bagaimana Peran Orang tua dalam Meningkatkan Minat Belajar Anak Pada Masa Pandemi Covid-19. Mengingat pentingnya peranan orang tua dalam mendidik anak, beberapa penelitian telah membuktikan bahwa orang tua memiliki peran yang sangat besar dalam membimbing anak dalam lingkup Pendidikan.

\section{Metode}

Pada penelitian ini peneliti menggunakan metode penelitian kualitatif. Menurut (Sugiyono, 2015) mengungkapkan bahwa penelitian kualitatif merupakan metode penelitian yang digunakan untuk meneliti pada kondisi objek yang alamiah, dimana peneliti berperan sebagai intruksi kunci. Penelitian kualitatif merupakan penelitian yang bersikap deskriptif.
Penelitian kualitatif ini mempunyai tujuan untuk mengetahui suatu fenomena yang dialami subjek dengan menceritakannya dalam bentuk kata-kata. Sumber data yang diambil oleh peneliti yaitu hasil wawancara peneliti dengan orang tua. Adapun instrument penelitian ini adalah orangtua di Plawad, Karawang Timur. Data yang diperoleh dari orang tua berupa opini secara individual yang berdasarkan jawaban dari hasil wawancara dengan peneliti. Selain sumber data hasil wawancara dari orang tua, bisa juga dapat berupa dokumentasi berbagai literatur yaitu berupa buku, jurnal, artikel ataupun yang berkaitan dengan penelitian.

\section{Hasil dan Pembahasan}

\section{PERAN ORANG TUA}

Menurut Anwar (dalam (Handayani, 2020)) Peranan artinya pelaku, pemain atau sesuatu yang merupakan bagian dari pemegang kendali untuk melaksanakan sesuatu atau orang yang memegang pimpinan. Peran orang tua sangat besar pengaruhnya terhadap keberhasilan anak dalam belajar. Tinggi rendahnya pendidikan orang tua, besar kecilnya penghasilan, cukup atau kurang perhatian dan bimbingan orang tua, rukun atau tidaknya orang tua, akrab atau tidaknya hubungan orang tua dengan anak-anak, tenang atau tidaknya situasi dalam rumah itu semuanya mempengaruhi minat belajar anak sehingga berdampak besar pada prestasi belajar anak.

Peran orang tua sangat penting terhadap menumbuhkan minat belajar anak sehingga prestasi anak tersebut dapat meningkat dengan baik serta kesadaran orang tua dalam membantu anak dapat menyelesaikan masalah yang di hadapi peserta didik, memberikan motivasi serta dukungan kepada anak. Memberikan pendidikan sejak dini kepada anak sebagai orang tua yang mendidik dengan tanggung jawab dan kedisiplinan, tanggung jawab sangat di perlukan untuk mengembangkan kepribadian anak. 
Menurut Abdul Wahid (dalam (Rohmawati, 2017)) Peranan orang tua sangat berpengaruh dalam keluarga untuk menciptakan ikatan emosional dengan anak, menciptakan suasana aman di rumah sehinga rumah merupakan tempat untuk kembali. memberikan kedisiplinan dan memperbaiki tingkah laku anak, menciptakan komunikasi yang baik diantara anggota keluarga.

Allah telah menjelaskan bahwa mendidik dan mengajar anak menjadi kebutuhan pokok dan suatu kewajiban bagi orang tua, dalam QS. At Tahrim:

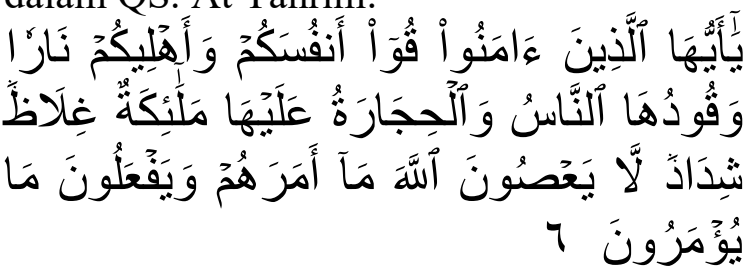

Artinya: "Hai orang-orang yang beriman, peliharalah dirimu dan keluargamu dari api neraka yang bahan bakarnya adalah manusia dan batu; penjaganya malaikatmalaikat yang kasar, keras, dan tidak mendurhakai Allah terhadap apa yang diperintahkan-Nya kepada mereka dan selalu mengerjakan apa yang diperintahkan.” Qs. At Tahrim ayat 6

Berdasarkan penjelasan ayat AlQur'an di atas, bahwa orangtua memiliki peran yang sangat penting juga dalam membimbing anak-anaknya dalam proses pendidikan dan pembelajaran seorang anak. Karena itu orang tua harus bisa melatih dan membiasakan seorang anak dalam perbuatan yang baik dan terpuji melalui keteladanan yang diberikan agar keyakinan agama tertanam dalam jiwanya. Dan setiap orangtua mempunyai kewajiban untuk memelihara dirinya dan keluarganya dari hal-hal yang dapat menjerumuskan ke dalam neraka dengan cara memberikan arahan, bimbingan, serta mengajari akhlak yang baik dan menjauhkannya dari akhlak yang buruk sejak usia dini. Begitu pentingnya peranan orang tua terhadap pendidikan anaknya karena menyangkut masa depan anak dan pendidikan yang harus dilaksanakan dengan penuh tanggung jawab. Sehingga kewajiban orang tua dalam mendidik dan membimbing anaknya menjadi seorang muslim yang berbakti kepada Allah dan Rasul-Nya dapat tercapai. Salah satunya adalah melakukan pendampingan terhadap anak dalam belajar dirumah, agar anak selalu semangat dalam belajar.

\section{MINAT BELAJAR}

Keberhasilan proses kegiatan belajar dan pembelajaran, selain di pengaruhi oleh faktor guru juga di pengaruhi oleh faktor siswa sendiri. Minat belajar merupakan aspek psikologis seseorang yang memperlihatkan diri dalam beberapa gejala seperti: gairah, keinginan, semangat, perasaan, suka untuk melakukan perubahan tingkah laku melalui berbagai kegiatan yang meliputi mencari pengetahuan dan pengalaman, dengan kata lain minat belajar adalah perhatian, rasa suka, ketertarikan seseorang (warga belajar) terhadap proses belajar yang dijalaninya dan yang kemudian ditunjukkan melalui keantusiasan, partisipasi dan keaktifan dalam mengikuti proses belajar yang ada.

Dengan adanya minat, dapat memperkuat ingatan seseorang terhadap apa yang telah dipelajarinya. Sehingga bisa dijadikan sebagai fondasi seseorang dalam proses pembelajaran suatu saat nanti. Minat mengarahkan perbuatan kepada tujuan dan dorongan bagi yang dilakukan tersebut. Dalam diri manusia terdapat dorongandorongan (motif-motif) yang mendorong manusia untuk berinteraksi dengan dunia luar, motif menggunakan dan melihat dunia luar (manipulate and exploring motives).

Ada beberapa pendapat yang dikemukakan para ahli tentang minat belajar. Minat dapat timbul melalui suatu pernyataan, rasa lebih suka dan rasa ketertarikan pada suatu hal atau aktifitas yang menunjukkan bahwa siswa lebih menyukai suatu aktifitas tersebut daripada sesuatu kegiatan yang lainnya, dapat pula diwujudkan melalui keikutsertaan dalam suatu kegiatan. Siswa yang memiliki minat terhadap kegiatan dan suatu pelajaran 
tertentu cenderung untuk memberikan perhatian yang lebih besar terhadap kegiatan dan pelajaran yang dilakukannya.

Selama pandemi Covid-19 berlangsung, pembelajaran secara daring dilakukan tidak hanya di Indonesia melainkan diseluruh penjuru dunia. Dalam segi pendidikan pembelajaran daring tentunya tidak terlepas dari peran orang tua sehingga dalam proses pembelajaran yang dilakukan secara daring ini orang tua dituntut mampu membimbing anak belajar dari rumah dan mampu menggantikan guru disekolah. Orang tua diharapkan mendampingi anak ketika pembelajaran sedang berlangsung. Peran orang tua saat mendampingi anak selama belajar dirumah menjadi sangat penting.

Siswa yang mempunyai minat terhadap suatu pelajaran akan mempelajarinya dengan sungguh-sungguh karena adanya daya tarik baginya, jadi dapat didefinisikan bahwa minat belajar merupakan suatu keadaan yang menunjukkan kecenderungan perhatian atau tertarik terhadap suatu pelajaran tertentu.

Keluarga adalah lingkungan yang pertama dikenal oleh seorang anak, dengan kata lain orang tua berkesempatan untuk memberikan yang terbaik untuk kehidupan seorang anak. Masalah pembentukan kepribadian seorang anak erat hubungannya dengan pengertian yang dimiliki oleh keluarga tentang minat belajar.

Menurut Yeni Kartika Sari (dalam Cut Venny Luciana, 2020:26) Anak akan belajar dengan efektif jika disertai dengan minat yang besar atau kuat terhadap pelajaran yang sedang dipelajari. Dengan kata lain minat belajar anak mempengaruhi prestasi belajarnya di sekolah. Apabila minat belajar anak dapat ditingkatkan maka kemungkinan besar prestasinya akan meningkat. Dengan demikian minat adalah dasar aktivitas atau kegiatan belajar anak.

Menumbuhkan minat belajar anak menjadi kendala yang dirasakan oleh orang tua selama mendampingi anak belajar dirumah dimasa pandemi Covid-19. Hal ini tentu menjadi hambatan yang berarti, mengingat bahwa membangun motivasi anak adalah cara yang ampuh dalam membentuk hasil akademis anak yang bagus.

Betapa pentingnya peranan orang tua dalam meningkatkan minat belajar anak, karena orang tua bertanggung jawab dalam menjalankan tugasnya dalam memberikan semangat dan dorongan kepada anak agar dapat tumbuh minat belajarnya untuk mencapai hasil yang lebih baik dan maksimal. Dalam usaha mendidik anak maka orang tua harus mampu menciptakan suasana dan kondisi yang tenang serta kondusif.

Peran orang tua sangat di perlukan untuk proses pembalajaran anak selama pembelajaran daring ini. Peran orang tua juga sangat diperlukan utuk memberikan edukasi kepada anak-anaknya. Pembelajaran online dinilai tetap mampu meningkatkan kualitas pembelajaran jika orang tua ikut serta membantu mendampingi anak belajar. Maka dari itu peran orang tua sangat diperlukan untuk mendampingi anak belajar selama pandemi.

\section{HASIL}

Sumber data yang diambil oleh peneliti yaitu hasil wawancara peneliti dengan orang tua di desa Plawad, Karawang Timur.

1. Berdasarkan hasil wawancara dengan Ibu Eneng pekerjaan sebagai Ibu Rumah Tangga.

a) Bagaimana peran anda sebagai orangtua dalam kegiatan belajar anak pada pembelajaran online saat ini?

Jawaban: "Saya selalu berusaha memberikan arahan pada saat pembelajaran online kepada anak saya seperti mengingatkannya belajar online, berusaha untuk menemani anak saat belajar online dan memberikan fasilitas yang dibutuhkan oleh anak".

b) Bagaimana cara ibu untuk meningkatkan semangat dan minat belajar anak dimasa pandemi saat ini?

Jawaban: "Memberikan motivasi pada anak saya, membimbing anak pada saat 
belajar agar anak saya lebih merasa dia di perhatikan dan memberikan apresiasi kepada anak dia ketika anak saya mendapatkan prestasi".

2. Berdasarkan hasil wawancara dengan Ibu Sukma sebagai Ibu Rumah Tangga.

a) Bagaimana peran anda sebagai orangtua dalam kegiatan belajar anak pada pembelajaran online saat ini?

Jawaban: "Saya sebagai orang tua mempunyai kewajiban dalam membimbing anak apalagi saat ini pembelajaran dilakukan secara daring dirumah masing-masing, saya berusaha agar anak mampu mempunyai prestasi yang baik di sekolah. Saya berusaha meluangkan waktu untuk mengawasi dan memberikan nasehat untuk belajar."

b) Bagaimana cara ibu untuk meningkatkan semangat dan minat belajar anak dimasa pandemi saat ini?

Jawaban: "Ditemenin saat belajar, didampingi, didukung berupa motivasi atau reward agar tetap semangat"

3. Berdasarkan hasil wawancara dengan Ibu Rita pekerjaan sebagai pedagang.

a) Bagaimana peran anda sebagai orangtua dalam kegiatan belajar anak pada pembelajaran online saat ini?

Jawaban: "Dalam kegiatan belajar anak saya pada pembelajaran online, Alhamdulillah saya sudah memberikan yang terbaik akan tetapi saya tidak selalu mendampingi anak saya dalam setiap pembelajaran online".

b) Bagaimana cara ibu untuk meningkatkan semangat dan minat belajar anak dimasa pandemi saat ini?

Jawaban: "Cara saya untuk bisa meningkatkan semangat belajar dimasa pandemi kepada anak saya yaitu saya ikut menemani anak ketika anak ada kesulitan dalam belajar, kemudian saya memberikan motivasi tentang pentingnya belajar walaupun dimasa pandemi, kemudian saya memberikan hadiah atau reward kepada anak saya jika tugas sekolah diselesaikan dengan baik"

\section{Simpulan}

Dengan adanya kebijakan dari pemerintah untuk work form home atau belajar di rumah, maka peran orang tua sebagai pengganti guru sangat penting. Peran orang tua juga sangat diperlukan utuk memberikan edukasi kepada anak-anaknya yang masih belum bisa memahami tentang pandemi yang sedang mewabah untuk tetap berdiam diri di rumah agar tidak terlular dan menularkan virus covid-19 ini. Berdasarkan penjelasan wawancara dapat disimpulkan bahwa dengan adanya pembelajaran di rumah mengembalikan tanggung jawab hakikat pendidikan pertama dan utama yaitu pendidikan di dalam keluarga. Oleh karena itu, peranan orang tua dalam pembelajran online ini sangat penting dalam memberikan minat belajar anak. Peran orang tua selama pembelajaran online atau di rumah diantaranya sebagai pembimbing, fasilitator, dan motivator. Tetapi tetap saja selama pembelajaran online ini tidak terlepas dari komunikasi yang terjadi antara guru dan orang tua.

Tetapi disisi lain pembelajaran online tetap saja membuat anak mengalami bosan dan stress, sehingga minat belajar anak cepat berubah dan dari situlah dapat memengaruhi prestasi belajarnya. Oleh karena itu, orang tua sebagai orang yang terdekat dengan anak memiliki peran yang sangat penting dalam meningkatkan minat dan prestasi belajar anak diantaranya dengan memberikan semangat, motivasi, memfasilitasi kebutuhan belajar anak, menjadi tempat untuk bertanya tentang pelajaran, dan memberikan apresiasi pada untuk setiap pencapaian anak yang telah diraih. 
Jurnal Edumaspul, 5 (2), Year 2021 - 55

(Sintia Septiani,Oyoh Bariah, Khalid Ramdhani)

\section{Daftar Pustaka}

[1] Cahyati, N., \& Kusumah, R. (2020, Juni). Peran Orang Tua Dalam Menerapkan Pembelajaran Di Rumah. Jurnal Golden Age, Universitas Hamzanwadi, 04, 153.

[2] Handayani, T. (2020). Peran Orang tua dalam Membimbing Anak Pada Pembelajaran Daring di Desa Ngrapah Kecamatan Banyu Biru Tahun Pelajaran 2019/2020. Peran Orang tua, 12.

[3] Kemendikbud. (2020, Maret 24). Surat Edaran Kemendikbud No 4 Tahun 2020 Tentang Pelaksanaan Kebijakan Pendidikan dalam Masa Darurat Penyebaran Corna Virus Disease (Covid-19). Retrieved from pusdiklat.kemdikbud.go.id:

https://pusdiklat.kemdikbud.go.id/su rat-edaran-mendikbud-no-4-tahun2020-tentang-pelaksanaankebijakan-pendidikan-dalam-masadarurat-penyebaran-corona-virusdisease-covid-1-9/

[4] Khalimah, S. N. (2020). Peran Orang tua dalam Pembelajaran Daring di MI Darul Ulum Pedurungan Kota Semarang Tahun Pelajaran 2020/2021. Peran Orang tua, 12.

[5] Permatasari, A. D., \& Haryati, N. (2020). Peran Orang Tua dalam
Meningkatkan Minat dan Hasil Belajar Siswa. Peran Orang tua, 697.

[6] Rohmawati, U. B. (2017, Juli 6). Peran Keluarga dalam Mengurangi Gangguan Emosional pada Anak Berkebutuhan Khusus. Peran Keluarga, 2, p. 109.

[7] Sudarsana, I. K., Ayu Made Yeni Lestari, N. G., \& dkk. (2020). Covid-19: Perspektif Pendidikan. (J. S. Kadek Aria Prima Dewi PF, Ed.) Denpasar: Yayasan Kita Menulis.

[8] Sugiyono. (2015). Metode Penelitian Kuantitatif. Kualitatif, dan $R \& D$. Bandung: Alfabeta.

[9] Yunitasari, R., \& Hanifah, U. (2020). Pengaruh Pembelajaran Daring terhadap Minat Belajar Siswa pada Masa COVID-19. Edukatif: Jurnal Ilmu Pendidikan, 2, $232-243$.

\section{Profil Penulis}

Nama Penulis Sintia Septiani, Iahir pada tanggal 20 September 1998, dan sedang menempuh pendidikan di Universitas Singaperbangsa Karawang. Prodi Pendidikan Agama Islam semester 8 dan akan menyelesaikan Strata 1 pada tahun ini. 